\title{
Who Benefits from Secondary Education Bursary Fund in Kenya?
}

\author{
John Mugun Boit ${ }^{1, *}$ \\ ${ }^{1}$ Moi University, School of Arts and Social Sciences, P.O.Box 3900 - 30100 Eldoret, Kenya \\ *Correspondence: Moi University, School of Arts and Social Sciences, P.O.Box $3900-30100$ \\ Eldoret, Kenya. Tel: 254-721-625-657. E-mail: jmugunboit@gmail.com
}

Received: May 26, 2015 Accepted: June 17, 2015 Published: June 29, 2015

doi:10.5296/ije.v7i2.7684 URL: http://dx.doi.org/10.5296/ije.v7i2.7684

\begin{abstract}
This study examined the effectiveness of the Secondary Education Bursary Fund SEBF in enhancing equity in access to secondary school educational opportunities. The discussion is guided by Rawls' theory of social justice as fairness (1971) upon which the concept of equity is grounded. The study is specifically influenced by the Difference Principle and the Criterion of Reciprocity on the basis of reasonable citizenship as espoused by Rawls. The Secondary Education Bursary Fund (SEBF) was established in 1994 by a presidential decree to help the socio-economically disadvantaged groups to access secondary education. The findings indicate that the bursary beneficiaries transcend all socio-economic boundaries and that the allocation mechanism did not, as was intended, effectively target bursary support to students from poor and vulnerable socio-economic groups. As a result, the fund has had little impact on equity in access to secondary education. There is therefore an urgent need to make necessary structural and management adjustments to the bursary fund to make it more responsive and selective to those in need of financial support. Of significance is adoption of management information systems to enable effective and efficient administration of the fund. The findings will inform management decisions geared towards revitalizing the fund as well as informing policy formulation and review and aid scholarly debate on issues of educational financial subsidies.
\end{abstract}

Keywords: Equity, bursary fund, secondary education, Kenya, socio-economic, access 


\section{Introduction}

Governments all over the world commit significant resources to education. Public subsidy in education has been justified for the enhancement of efficiency and equity (Psacharopoulos and Wood hall, 1985). Nevertheless, it is doubtful as to whether such subsidies reduce the level of disadvantage of the poor. Educational subsidies have been found to be disadvantageous to the poor since measures of ability tend to correlate with the socio-economic background (KIPPRA, 2007). Hence, using ability to allocate education opportunities does not bring about equality of opportunity of any kind. Ideally, students should be subsidized according to their wealth to cover all or most of the cost of education. Studies on the distribution of public subsidies across the world have had to conclude that subsidies for education are simply a transfer of income from poor tax payers to the rich (Albrech, and Ziderman, 1991; Karani, 1995). However, there is evidence that at the lower levels of the education sub-sector the marginal social benefits are higher than the private benefits (Pacharopoulos, \& Woodhall, 1985; Barr 2000).

The concern for equity, access and social class bias has been, and continue to be a motivating factor in the government's intervention in the education sector. The principle objective has been to realize an education system aimed at removing social injustices and disparities between regions, sexes, social and economic groups and one that equalizes economic opportunities among all citizens (Lewin, 2009; Oduaran \& Bhola 2006). Thus, policy documents since independence have reiterated the importance of education in eliminating social disparities and in equalizing economic opportunities among all citizens. For instance, the Ominde Report (GOK, 1965) urged the government to provide equal educational opportunities to all children consistent with the Sessional Paper on African socialism and its application to Planning in Kenya. In Sessional Paper No.1 of 2005 on Policy Framework for Education, Training and Research (GOK, 2005a) the government emphasized the eradication of existing disparities through increased government support and that policy measures are required to address the access to secondary education by the poor and the disadvantaged groups in order to realize the country's overall educational goals.

As a social service, education has not spread evenly. Its distribution is characterized by inequalities in terms of access, achievement and transition. Efforts to expand education opportunities as crafted neatly in education policies have not democratized education opportunities but have instead preserved and perpetuated inequalities. This has necessitated pressure to give priority to equity objectives whose ultimate goal is to enhance social justice. A study by Akinkugbe and Kunene (2001) in Swaziland concluded that the distribution of public spending on education is not equitable among different levels of education.

As part of the government strategy to ensure equity in access to secondary education, the Kenya government introduced bursary fund in the 1993/1994 financial year. The fund is aimed at increasing access to secondary education, ensuring student retention, promoting transition and completion rates, and reducing disparities and inequalities in the provision of secondary education (GOK, 2005b).

Until 2003, the responsibility of identifying bursary beneficiaries rested with the schools' Board of Governors (B.O.G.) a system considered ineffective in targeting the vulnerable in 
2003, the NARC government established the Constituency Bursary Fund (CBF) through an Act of Parliament to administer the disbursement of bursary funds. This was meant to allow the local community to correctly identify needy cases (Kimenyi, 2005). Nevertheless, public debate cast doubt on the ability of the fund to cushion the poor and the vulnerable from the high cost of secondary education. The contention was that the bursary fund did not benefit the intended group but instead served to perpetuate social economic inequalities (KIPPRA. 2007).

To address the challenges of equity and participation, the crucial role of bursaries is reiterated by the Interim Poverty Reduction Paper 2000-2003 (GOK, 2000). In recognition of the role of education in reducing intergenerational inequity and to ensure that inequalities are not transferred from one generation to the next in perpetuity, the government (GOK, 2005) committed itself to address the challenges of equity, access and equality of opportunity to meet the challenges of the $21^{\text {st }}$ century.

The shift in the management of bursary funds from the BOG to the CBF initially hailed as the best move soon received condemnation and public outcry. Complaints abound with regard to the failure of the fund to target the needy. The general public feeling was that needy cases missed out on the bursary kitty while those from the well-off families benefited. There was doubt on the capacity of the fund to realize equality in educational opportunities necessary to narrow the gap between the socio-economic groups (GOK, 2006).

This study sought to answer the following research questions;

(i) Who are the beneficiaries of bursary funds by socio-economic background?

(ii) How effective is the current bursary allocation mechanism in targeting the vulnerable?

(iii) What is the impact of the bursary fund on equity in access to secondary education?

\section{Methodology}

\subsection{The Area of Study}

The study was carried out in Trans-Nzoia West District of Trans-Nzoia County of Kenya. The district borders Mt. Elgon and Kwanza Districts to the north, Bungoma North District to the west, Lugari to the South-West, Uasin-Gishu to the South East, and Trans-Nzoia East District to the East.

\subsection{Research Design}

The investigation adopted a descriptive survey research design to systematically gather factual quantifiable information.

\subsection{The Study Population}

The target population of the study comprised 2674 form three students and school administrators in the 49 secondary schools, 5 Area Education Officers, 15 members of the provincial administration at locational administrative levels and opinion leaders in the district. 


\subsection{Sample and Sampling Procedures}

Stratified random sampling technique was used to select 17 out of the 49 secondary schools in the district to ensure proportionate representation of all school categories in the sample as in the population. The schools were selected according to the three categories; District, Provincial and Private. The form three students were chosen because it was believed they could provide reasonably consistent information for about three years of the period under study. While the form four students would have been ideal, the study was conducted at the time they were writing their Kenya certificate of secondary examinations hence it would have been inconveniencing for them to participate. The survey sample of 335 participants was randomly selected from the school category on the basis of a generalized scientific guideline for sample size decision as given by Krejcie and Morgan (1970).

Survey questionnaires comprising closed and open- ended items were carefully designed to capture information on the socio-economic backgrounds of the potential bursary beneficiaries, allocation procedures, perceptions on the performance of the fund, as well as suggestions for improvement.

School admission registers, class registers and correspondences with the (CBC) were examined using the document analysis for information on the socio-economic backgrounds of the bursary beneficiaries, repetition and drop-out rates, and trends in bursary awards to students in the sample schools from 2003 - 2007. This was corroborated with information from records at the District Education Office for bursary disbursements to schools.

\subsection{Reliability and Validity of Research Instruments}

A reliability coefficient of $\mathrm{r}=0.86$ using split half reliability test was obtained and this was considered sufficient to be used to make accurate predictions (Bryman, 2007). Further, validity of the instruments was obtained through pilot testing on students of the neighboring district schools with similar socio-economic characteristics and who did not participant in the study. (Borg, 1981). Also expertise advice was solicited from experienced researchers to determine the extent to which the instruments would actually measure what it was supposed to measure. Appropriate check on language use, vocabulary and cultural sensitivity was also confirmed. The advice and suggestions given were incorporated into the instrument (Cohen, Manion, \& Morrison, 2007).

\section{Results}

\subsection{Background Information of Student Respondents}

The Table 1 below presents the education background of student respondents in terms of the type of primary schools attended, KCPE performance as well as admission year in secondary school. 
Table 1. Education Background of the Respondents

\begin{tabular}{llll}
\hline Items & Description & Frequency & Percentage \\
\hline Type of primary & Public day & 259 & 77 \\
school attended & Public boarding & 23 & 7 \\
& Private day & 23 & 7 \\
& Private boarding & 30 & 9 \\
& Below 250 & 16 & 5 \\
KCPE marks & $250-300$ & 143 & 43 \\
& $301-350$ & 117 & 35 \\
Year of admission & 51 & 15 \\
& $351-400$ & 8 & 2 \\
& Above 400 & 193.1. & 6 \\
& 2004 & 198 & 59 \\
& 2006 & 47 & 14 \\
& 2007 & 71 & 21
\end{tabular}

As shown in table 1 above 259 (77\%) of the respondents attended public day primary schools while $23(7 \%)$ attended public boarding and private day respectively while $30(9 \%)$ private day. This distribution implies that only about $25 \%$ of the respondents' parents could afford boarding and or private primary education for their children. The study also revealed that majority of the respondents (78\%) scored between 250-350 marks in their K.C.P.E examinations.

With regard to the year of the respondents' admission in their various schools, it was noted that some students may have repeated at least one class, while others had joined their schools on transfer. The new admissions implied that some students had dropped out of school thus creating room for replacement. Secondly, it could also imply that student mobility across school categories could have been influenced by the financial ability to meet fees in the schools of choice.

\subsection{Respondent's Parents Level of Education and Number of Siblings in Higher Education}

The findings showed that $20 \%$ of the respondents had fathers who had attained primary level of education as compared to $34 \%$ for their mothers. Additionally, $26 \%$ and $36 \%$ of fathers and mothers had secondary level of education respectively while those with college level education were $38 \%$ and $26 \%$ for fathers and mothers respectively. Fathers with university education were $15 \%$ against only $4 \%$ for mothers. It is instructive to note that a child's education opportunities are determined by the educational background of parents (Knight, and Sabot, 1990). 


\section{Macrothink}

Table 2. Level of Education of Respondents' Parents and Respondents' Siblings Enrolled in other Educational Institutions

\begin{tabular}{llll}
\hline Education level & Parent & Frequency & Percentage \\
\hline Primary & Father & 67 & 20 \\
Secondary & Mother & 113 & 34 \\
& Father & 88 & 26 \\
College & Mother & 122 & 36 \\
& Father & 129 & 38 \\
University & Mother & 86 & 26 \\
& Father & 51 & 15 \\
Totals & Mother & 14 & 4 \\
& Father & $\mathbf{3 3 5}$ & $\mathbf{1 0 0}$ \\
& Mother & $\mathbf{3 3 5}$ & $\mathbf{1 0 0}$ \\
\hline
\end{tabular}

\begin{tabular}{lcc}
\hline Sibling in secondary school/ college & Frequency & Percentage \\
\hline Nil & 79 & 23 \\
$1-2$ & 151 & 45 \\
$3-4$ & 80 & 24 \\
$5-6$ & 21 & 6 \\
7 above & 4 & 2 \\
Total & $\mathbf{3 3 5}$ & $\mathbf{1 0 0}$ \\
\hline
\end{tabular}

Out of 335 participants $79(23 \%)$ had no siblings in secondary schools and/or colleges, $151(45 \%)$ had at least $1-2$, while $80(24 \%)$ had about $3-4$. This compares with $21(6 \%)$ who had 5-6 and only $4(2 \%)$ had either 7 or more siblings in such institutions. With over $75 \%$ having at least a sibling in secondary school, and in consideration of the high cost of education the majority of the students would require some form of financial support as most of them feature at the lower end of the socio-economic status as reflected by the level of education of either parent.

\subsection{Nature and Composition of the Beneficiaries}

Table 3. Nature and Composition of the Beneficiaries

\begin{tabular}{llll}
\hline Items & Description & Frequency & Percentage \\
\hline Parental status & Total orphaned & 24 & 19 \\
& Partial orphaned & 36 & 28 \\
& Not orphaned & 67 & 53 \\
Parents occupation & Civil servant & 48 & 38 \\
& Politician & 5 & 4 \\
& Farmer & 18 & 14 \\
& Businessman & 14 & 11 \\
& Peasant farmer & 38 & 30 \\
& Others & 4 & 4 \\
\hline
\end{tabular}


School records of bursary awards for the year 2007 show that of the 127 beneficiaries, 24 (19\%) were totally orphaned, 36 (28\%) partially orphaned while $67(52 \%)$ had both their parents alive.

With regard to the occupation of parents and/or guardians, $67 \%$ of the beneficiaries came from family backgrounds that were either of civil servants, politicians, civic leaders, businessmen and farmers while $34 \%$ families of peasant farmers and small scale traders. The fact that the majority of children from families perceived to be fairly well off (civil servants, politicians, farmers and businessmen) benefited from a kitty established for the poor raises concern on the administration of the fund or the allocation criteria.

\subsection{Students' Perceptions of the Impact of the Bursary Fund}

Respondents perceptions of the application procedure and the impact of bursary to assist financially needy students were assessed on a 5 point Likert scale and the responses are presented in the table below.

Table 4. Students' Perceptions of the Impact of the Bursary Fund

\begin{tabular}{lllllll}
\hline Items & SA & A & U & D & SD & MEAN \\
& $\mathbf{5}$ & $\mathbf{4}$ & $\mathbf{3}$ & $\mathbf{2}$ & $\mathbf{1}$ & \\
\hline Bursary has enabled & $\mathrm{F}$ & $\mathrm{F}$ & $\mathrm{F}$ & $\mathrm{F}$ & $\mathrm{F}$ & \\
orphans to learn. & $(8)$ & 35 & 41 & 133 & 100 & \\
Applicants cheat to & 26 & 32 & 104 & 108 & 64 & \\
get bursary & $(8)$ & $(10)$ & $(31)$ & $(32)$ & $(19)$ & 2.5 \\
Application forms & 73 & 103 & 32 & 74 & 52 & \\
are easily available & $(22)$ & $(31)$ & $(10)$ & $(22)$ & $(16)$ & 3.2 \\
My HT recommends & 78 & 80 & 26 & 75 & 76 & \\
all for bursary & $(23)$ & $(24)$ & $(8)$ & $(22)$ & $(23)$ & 3 \\
Feedback on bursary & 32 & 64 & 33 & 84 & 122 & 2.6 \\
application is timely & $(10)$ & $(19)$ & $(10)$ & $(25)$ & $(36)$ & \\
One can appeal for & 32 & 39 & 62 & 97 & 104 & 2.4 \\
more funds & $(10)$ & $(12)$ & $(19)$ & $(29)$ & $(31)$ & \\
Orphans are well & 63 & 76 & 27 & 100 & 68 & 2.8 \\
catered for & $(19)$ & $(23)$ & $(8)$ & $(30)$ & $(20)$ & \\
Application process & 52 & 79 & 26 & 82 & 9 & 2.5 \\
is easy and straight & $(16)$ & $(24)$ & $(8)$ & $(24)$ & $(3)$ & \\
\hline
\end{tabular}

\section{Legend: \% in parentheses}

Asked if the bursary fund had enabled orphans to access education, 26(8\%) of the respondents strongly agreed, 35(11\%) agreed, 41(12\%) were undecided, 133(40\%) disagreed while100 (30\%) strongly disagreed. Similarly, 26(8\%) strongly agreed that applicants often cheat to get bursary funds, 32(10\%) agreed, 104(31\%) were undecided, 108(32\%) disagreed as 64(19\%) strongly disagreed. 
Further students opinion was sought with regard to the application and processing of the bursary funds. Responses showed that $73(22 \%)$ of the respondents strongly agreed, 103(31\%) agreed, 32(10\%) were undecided, 74(22\%) disagreed while 52(16\%) strongly disagreed that the application forms were readily accessible to students. Views were also sought with regard to whether school administrators recommending all applicants for bursary awards. It emerged that $78(23 \%)$ of the respondents strongly agreed, $80(24 \%)$ agreed, 26(8\%) were undecided, $75(22 \%)$ disagreed and 76(23\%) strongly disagreed.

On whether feedback on bursary application is timely, 36(10\%) of the respondents strongly agreed, 64(19\%) agreed, 33(10\%) were undecided as 84(25\%) and 122(36\%) disagreed and strongly disagreed respectively. Very few respondents thought there was recourse for appeal to the $\mathrm{CBC}$ if they were unsuccessful with $32(10 \%)$ strongly agreeing and 39(12\%) agreeing. However, 62(19\%) were undecided, 97(29\%) disagreed while 104(31\%) strongly disagreed. The statement checking whether there was ease and straight forwardness in the application procedure achieved a mean score of 2.5. It appears that the majority of the respondents were undecided as to whether the bursary fund catered for orphans as this achieved a mean score of 2.8

The implication is that the application procedure, the methods of identifying beneficiaries and dishonesty among some students and or parents combine to deny majority of the vulnerable children access to the funds meant to subsidize their education. Consequently there will be frequent interruptions of their education programmes when they get send home from school for non-completion of fees.

\subsection{School Administrators' Perceptions of the Socio-economic Composition of Bursary Beneficiaries}

The socio - economic composition of the bursary beneficiaries was responded to on a 5 point Likert scale as illustrated in Table 5 below.

On the question that the bursary beneficiaries were genuinely needy cases, only $1(6 \%)$ agreed, $3(18 \%)$ were undecided as compared to $10(59 \%)$ who disagreed. As to whether the beneficiaries were from poor backgrounds $2(12 \%)$ strongly agreed, 3(18\%) agreed as compared to $10(59 \%)$ who disagreed.

The perceived role of the bursary in assisting students disadvantaged in one way or another by the HIV/AIDS pandemic was weighted at a mean of 2.5 . Only 1(6\%) respondents strongly agreed that the fund had benefited affected children, 4(24\%) agreed as compared to 7(41\%) who disagreed and $4(24 \%)$ who strongly disagreed. With regard to gender consideration in the award of bursary, $48 \%$ affirmed. On the statement that bursary beneficiaries came from diverse backgrounds, 4(24\%) strongly agreed, with 3(18\%) agreed, 4(24\%) were undecided, 3(18\%) and a similar response respectively agreed and strongly disagreed. 
Table 5. School Administrators' Perceptions of the Bursary Beneficiaries

\begin{tabular}{|c|c|c|c|c|c|c|}
\hline \multirow[t]{2}{*}{ Items } & $\begin{array}{l}\text { SA } \\
5\end{array}$ & $\begin{array}{l}\text { A } \\
4\end{array}$ & $\begin{array}{l}\mathbf{U} \\
\mathbf{3}\end{array}$ & $\begin{array}{l}\text { D } \\
2\end{array}$ & SD & Mean \\
\hline & $\mathrm{F}$ & $\mathrm{F}$ & $\mathrm{F}$ & $\mathrm{F}$ & $\mathrm{F}$ & \\
\hline $\begin{array}{l}\text { Bursary beneficiaries are genuinely } \\
\text { needy cases }\end{array}$ & & $\begin{array}{l}1 \\
(6)\end{array}$ & $\begin{array}{l}3 \\
(18)\end{array}$ & $\begin{array}{l}10 \\
(59)\end{array}$ & $\begin{array}{l}3 \\
(18)\end{array}$ & 2.4 \\
\hline $\begin{array}{l}\text { Beneficiaries are from poor } \\
\text { backgrounds }\end{array}$ & $\begin{array}{l}1 \\
(6)\end{array}$ & $\begin{array}{l}1 \\
(6)\end{array}$ & $\begin{array}{l}3 \\
(18)\end{array}$ & $\begin{array}{l}10 \\
(59)\end{array}$ & $\begin{array}{l}2 \\
(12)\end{array}$ & 2.7 \\
\hline $\begin{array}{l}\text { Beneficiaries are children affected } \\
\text { by the HIV/AIDS }\end{array}$ & $\begin{array}{l}1 \\
(6)\end{array}$ & $\begin{array}{l}4 \\
(24)\end{array}$ & $\begin{array}{l}1 \\
(6)\end{array}$ & $\begin{array}{l}7 \\
(41)\end{array}$ & $\begin{array}{l}4 \\
(24)\end{array}$ & 2.5 \\
\hline $\begin{array}{l}\text { Boys and girls benefit equally from } \\
\text { bursary }\end{array}$ & $\begin{array}{l}4 \\
(24)\end{array}$ & $\begin{array}{l}4 \\
(24)\end{array}$ & $\begin{array}{l}1 \\
(6)\end{array}$ & $\begin{array}{l}7 \\
(41)\end{array}$ & $\begin{array}{l}1 \\
(6)\end{array}$ & 3.7 \\
\hline $\begin{array}{l}\text { Students from diverse backgrounds } \\
\text { benefit equally }\end{array}$ & $\begin{array}{l}4 \\
(24)\end{array}$ & $\begin{array}{l}3 \\
(18)\end{array}$ & $\begin{array}{l}4 \\
(25)\end{array}$ & $\begin{array}{l}3 \\
(18)\end{array}$ & $\begin{array}{l}3 \\
(18)\end{array}$ & 3.7 \\
\hline Orphans are well catered for & $\begin{array}{l}1 \\
(6)\end{array}$ & $\begin{array}{l}4 \\
(24)\end{array}$ & $\begin{array}{l}1 \\
(6)\end{array}$ & $\begin{array}{l}6 \\
(35)\end{array}$ & $\begin{array}{l}5 \\
(29)\end{array}$ & 2.7 \\
\hline $\begin{array}{l}\text { Beneficiaries are socio-politically } \\
\text { connected }\end{array}$ & $\begin{array}{l}1 \\
(6)\end{array}$ & $\begin{array}{l}7 \\
(41)\end{array}$ & $\begin{array}{l}7 \\
(41)\end{array}$ & $\begin{array}{l}2 \\
(12)\end{array}$ & & 3.9 \\
\hline $\begin{array}{l}\text { Beneficiaries are from well-off } \\
\text { families }\end{array}$ & $\begin{array}{l}1 \\
(6)\end{array}$ & $\begin{array}{l}10 \\
(59)\end{array}$ & $\begin{array}{l}3 \\
(18)\end{array}$ & $\begin{array}{l}2 \\
(12)\end{array}$ & $\begin{array}{l}1 \\
(6)\end{array}$ & 3.9 \\
\hline $\begin{array}{l}\text { Beneficiaries are perennial fee } \\
\text { defaulters }\end{array}$ & $\begin{array}{l}3 \\
(18)\end{array}$ & $\begin{array}{l}6 \\
(35)\end{array}$ & $\begin{array}{l}2 \\
(12)\end{array}$ & $\begin{array}{l}4 \\
(24)\end{array}$ & $\begin{array}{l}2 \\
(12)\end{array}$ & 3.7 \\
\hline $\begin{array}{l}\text { Beneficiaries are from illiterate } \\
\text { backgrounds }\end{array}$ & & $\begin{array}{l}2 \\
(12)\end{array}$ & $\begin{array}{l}3 \\
(18)\end{array}$ & $\begin{array}{l}4 \\
(24)\end{array}$ & $\begin{array}{l}8 \\
(47)\end{array}$ & 2.2 \\
\hline
\end{tabular}

\section{Legend: \% in parentheses}

On whether the fund had taken care of the orphans, 30\% agreed as compared to $64 \%$ who disagreed. As to the statement that the beneficiaries were socio-politically connected $47 \%$ were in agreement compared to $12 \%$ who disagreed giving a mean of 3.9. Respondents also indicated that the bursary fund did not give preference to children from illiterate family backgrounds this achieved a mean score of 2.2. The overall result indicates that the fund was particularly not discriminative enough since as indicated beneficiaries came from all socio-economic backgrounds.

\subsection{Administrators perceptions on the Impact of the Bursary Fund}

A 5 point Likert scale was used to gather views from school administrators on the impact of the bursary fund The responses are described in table 6 below. 
Table 6. Administrators perceptions on the Impact of Bursary

\begin{tabular}{|c|c|c|c|c|c|c|}
\hline Items & $\begin{array}{l}\mathbf{S A} \\
\mathbf{5}\end{array}$ & $\begin{array}{l}\text { A } \\
4\end{array}$ & $\begin{array}{l}\mathbf{U} \\
\mathbf{3}\end{array}$ & $\begin{array}{l}\text { D } \\
2\end{array}$ & $\begin{array}{l}\text { SD } \\
1\end{array}$ & Mean \\
\hline & $\mathrm{F}$ & $\mathrm{F}$ & $\mathrm{F}$ & $\mathrm{F}$ & $\mathrm{F}$ & \\
\hline $\begin{array}{l}\text { Bursary funds are adequate to meet students } \\
\text { education needs }\end{array}$ & & & & $\begin{array}{l}10 \\
(58)\end{array}$ & $\begin{array}{l}7 \\
(41)\end{array}$ & 1.5 \\
\hline $\begin{array}{l}\text { The fund has enabled the vulnerable to access } \\
\text { education }\end{array}$ & & $\begin{array}{l}5 \\
(29)\end{array}$ & $\begin{array}{l}4 \\
(24)\end{array}$ & $\begin{array}{l}8 \\
(47)\end{array}$ & & 2.8 \\
\hline $\begin{array}{l}\text { The fund has enhanced equality in education } \\
\text { opportunities }\end{array}$ & & $\begin{array}{l}6 \\
(35)\end{array}$ & $\begin{array}{l}2 \\
(12)\end{array}$ & $\begin{array}{l}7 \\
(41)\end{array}$ & $\begin{array}{l}2 \\
(12)\end{array}$ & 2.7 \\
\hline $\begin{array}{l}\text { Bursary has narrowed disparity in school } \\
\text { infrastructural development. }\end{array}$ & & $\begin{array}{l}3 \\
(18)\end{array}$ & $\begin{array}{l}4 \\
(24)\end{array}$ & $\begin{array}{l}10 \\
(58)\end{array}$ & & 2 \\
\hline $\begin{array}{l}\text { Some students benefits from more than one } \\
\text { constituency }\end{array}$ & & $\begin{array}{l}10 \\
(58)\end{array}$ & $\begin{array}{l}3 \\
(18)\end{array}$ & $\begin{array}{l}4 \\
(24)\end{array}$ & & 3.3 \\
\hline $\begin{array}{l}\text { Bursary fund has marginalized disadvantaged } \\
\text { groups }\end{array}$ & & $\begin{array}{l}4 \\
(24)\end{array}$ & $\begin{array}{l}2 \\
(12)\end{array}$ & $\begin{array}{l}6 \\
(35)\end{array}$ & $\begin{array}{l}4 \\
(24)\end{array}$ & 2.4 \\
\hline $\begin{array}{l}\text { Bursary funds have enhanced transition to } \\
\text { secondary education }\end{array}$ & & $\begin{array}{l}8 \\
(47)\end{array}$ & $\begin{array}{l}1 \\
(6)\end{array}$ & $\begin{array}{l}7 \\
(41)\end{array}$ & $\begin{array}{l}1 \\
(6)\end{array}$ & 2.9 \\
\hline $\begin{array}{l}\text { The fund has narrowed disparity in education } \\
\text { opportunities among groups }\end{array}$ & & & & $\begin{array}{l}10 \\
(58)\end{array}$ & $\begin{array}{l}7 \\
(41)\end{array}$ & 1.6 \\
\hline $\begin{array}{l}\text { Bursary funds has enhanced students } \\
\text { retention rates }\end{array}$ & & $\begin{array}{l}9 \\
(53)\end{array}$ & $\begin{array}{l}3 \\
(18)\end{array}$ & $\begin{array}{l}5 \\
(29)\end{array}$ & & 3.2 \\
\hline Bursary fund has enhanced completion rates & & $\begin{array}{l}8 \\
(47)\end{array}$ & $\begin{array}{l}1 \\
(6)\end{array}$ & $\begin{array}{l}7 \\
(41)\end{array}$ & $\begin{array}{l}1 \\
(6)\end{array}$ & 2.9 \\
\hline
\end{tabular}

\section{Legend: \% in parentheses}

On the statement that checked if funds were adequate to meet educational needs of the beneficiaries, $10(58 \%)$ respondents disagreed while $7(41 \%)$ strongly disagreed. However, $59(29 \%)$ agreed that the funds, had enabled the vulnerable to access education as compared to $8(47 \%)$ that disagreed. It was also perceived that the bursary fund had enhanced equality in educational opportunities with $6(35 \%)$ agreeing, $7(41 \%)$ undecided as $2(12 \%)$ strongly disagreeing.

In response to the role of bursary in narrowing the disparity in school infrastructural development, $18 \%$ agreed as compared to $24 \%$ who were undecided, and $58 \%$ who disagreed.

Asked if the fund had marginalized the disadvantaged, 24\% agreed, as compared to $58 \%$ who disagreed. Similarly, $58 \%$ disagreed that the bursary fund had narrowed disparity in education opportunities among socio-economic groups, as $41 \%$ strongly disagreed. With regard to the funds' enhancement of access, retention and transition rates, a weighted mean response of 3 was recorded indicating undecided.

Respondents also indicated that the bursary fund was unfairly exploited by some applicants 
who transcended their constituency boundaries with $58 \%$ of the respondents agreeing that some students received bursary awards from more than one constituency. This response compares favorably with that of student respondents that pointed at dishonesty of some applicants in their quest to secure financial assistance from several the bursary funds.

\section{Conclusions and Recommendations}

The main focus of this study was to answer three research questions in order to provide a better understanding of the effectiveness and efficiency of the bursary fund from the perspectives of secondary school students and teachers. The questions asked were; who are the beneficiaries of bursary funds by socio-economic background? how effective is the current bursary allocation mechanism in targeting the vulnerable? What is the impact of the bursary fund on equity in access to secondary education?

There is no doubt that the bursary fund has assisted many needy students to access secondary school education, the general perception however is that beneficiaries transcend social classes. The majority of beneficiaries were found to be children from well off families, with $63 \%$ being children whose parents were civil servants, politicians, farmers or businessmen. Only $30 \%$ belonged to peasants and small scale traders like hawkers. School administrators' perceptions of the socio-economic composition of bursary beneficiaries also confirmed that the beneficiaries of bursary funds were not particularly the poor and vulnerable as indicated by low means on all items checking on the socio - economic composition of the bursary beneficiaries. The item "bursary beneficiaries are genuinely needy cases" achieved a negative perception with a mean score 2.4 while on the item "bursary beneficiaries are genuinely needy cases" was 2.7. The Items "beneficiaries are children affected by the HIV/AIDS" was scored at 2.5. Respondents also indicated that the bursary fund did not give preference to children from illiterate family backgrounds with a mean score of 2.2. There were positive responses on the items "Beneficiaries are socio-politically connected" and "beneficiaries are from well-off families" with mean values of 3.9 respectively all measured on a five point type scale with 1 being strongly disagree and 5 strongly agree.

This finding is an indication that the bursary allocation mechanism was ineffective in targeting the vulnerable children and in disbursing bursary funds to those most in need. In addition, the guidelines issued for bursary disbursement from the Ministry of Education appear to have been flouted. As a result, the fund has had little impact on lives of the majority of the poor and vulnerable students. Both students and school administrators were of the view that the bursary fund did not have an impact on the vulnerable students as indicated by low mean values ranging between 2.3 and 3 on all bursary fund impact items. The item "bursary has enabled orphans to learn achieving 2.3, and "application forms are easily available" achieving 3 . The administrators similarly rated negatively the item "the fund has narrowed disparity in education opportunities among groups" which achieved a mean score of 1.6 while they were undecided on both the items "bursary funds has enhanced students retention rates" at 3.3 and "some students benefit from more than one constituency with a mean value, 3.3 respectively. 
It is therefore imperative that bursary allocation mechanisms are improved to make the fund more effective in identifying needy and deserving students for financial support. Structural changes should be made to the bursary fund processing procedures to include among other things participation of key stakeholders such as parents, teachers, Ministry of Education Officials and beneficiaries for purposes of enhancing accountability and transparency. Adoption of a modern electro-mechanical system of processing and awarding bursary funds that minimizes human contact and reduces the possibility of the allocation criteria being manipulated is recommended to enable effective and efficient administration of the secondary education bursary fund in Kenya.

\section{References}

Akinkugbe, O., \& Kunene, V. (2001). Education Financing and Budgetary Reforms in Africa: The Swaziland Case Study. Paris: CODESERIA.

Albrecht, D., \& Ziderman, A. (1991). Deferred Cost Recovery for Higher Education: Student Loan program in developing countries. World Bank Discussion paper \# 137. http://dx.doi.org/10.1596/0-8213-1952-3

Barr, N. (2000). The benefits of education: What we know and don't in Economic Growth and Government Policy, Papers presented and a HM Treasury Seminar, October, 2000.

Borg, W.R. (1981). Applying Educational Research: a Practical Guide for Teachers. New York: Longman.

Bryman, A. (2007). Barriers to Integrating Quantitative and Qualitative Research. Journal of Mixed Methods Research, 1, 8-22. http://dx.doi.org/10.1177/2345678906290531

Cohen, L., Manion, L., \& Morrison, K. (2007). Research Methods in Education (6 ${ }^{\text {th }}$ Ed.). London \& New York: Routledge.

G.O.K (2000). Interim Poverty Reduction Strategy Paper 2000-2003. Nairobi: Government Printer.

G.O.K. (2001). Poverty Reduction Strategy Paper (PRSP) 2001-2004. Nairobi: Government Printer.

G.O.K. (2004). Economic Survey: Report of the Central Bureau of Statistics and the Ministry of Planning and Development. Nairobi: Government Printer.

G.O.K. (2005a). Sessional Paper No. 1 of 2005: A Policy Framework for Educational Training and Research. Government Press: Nairobi.

G.O.K. (2005b). Kenya Education Sector Support Programme 2005-2010; Delivering Quality Education and Training to All. Government Press: Nairobi.

G.O.K. (2006). Ministry of Education Strategic Plan 2006-2011. Nairobi: Government Printer. Karani, F.A. et al. (1995). Cost and Financing of Education in Kenya. Study-2Acces, Quality 
and Equity in Secondary Education, Nairobi: Ministry of Education and Culture.

Kimenyi, S.M. (2005). Efficiency and Efficacy of Kenya's Constituency Development Fund: Theory and Evidence. Connecticut: University of Connecticut.

KIPPRA. (2007). Policy Review Issue No. 3, 2007. Making Public Secondary Education Affordable. Bursary Scheme Implementation and Challenges. IPAR.

Knight, J.B., \& Sabot, R.H. (1990). Education, Productivity and Inequality: The Eastern Africa Natural Experiment. Washington DC: the World Bank.

Krejcie. R., \& Morgan D. (1970). Determining Sample Size for Research Activities. Educational and Psychological Measurement, 30, 607-610

Lewin, K.M. (2009). Access to Education in Sub-Saharan Africa: patterns, problems and possibilities. Journal of Comparative Education, 45(2), 151-174. http://dx.doi.org/10.1080/03050060902920518

Oduaran, A., \& Bhola, H. (2006). Widening Access to Education as a Social Justice. Springer: Netherlands. http://dx.doi.org/10.1007/1-4020-4324-4

Pacharopoulos, G., \& Woodhall, M. (1985). Education for Development. Oxford: University Press.

Rawls, J. (1996). Political Liberalism. Columbia: Columbia University Press.

\section{Copyright Disclaimer}

Copyright for this article is retained by the author(s), with first publication rights granted to the journal.

This is an open-access article distributed under the terms and conditions of the Creative Commons Attribution license (http://creativecommons.org/licenses/by/3.0/). 